\title{
Personal networking in Russia and China
} BLAT and GUANXI

\author{
Michailova, Snejina; Worm, Verner
}

Document Version

Final published version

Publication date:

2002

License

CC BY-NC-ND

Citation for published version (APA):

Michailova, S., \& Worm, V. (2002). Personal networking in Russia and China: BLAT and GUANXI.

Link to publication in CBS Research Portal

\section{General rights}

Copyright and moral rights for the publications made accessible in the public portal are retained by the authors and/or other copyright owners and it is a condition of accessing publications that users recognise and abide by the legal requirements associated with these rights.

\section{Take down policy}

If you believe that this document breaches copyright please contact us (research.lib@cbs.dk) providing details, and we will remove access to the work immediately and investigate your claim. 
Snejina Michailova

Verner Worm

Personal Networking

in Russia and China:

BLAT and GUANXI

WP 15-2002 


\title{
PERSONAL NETWORKING IN RUSSIA AND CHINA: $B L A T$ AND GUANXI
}

\author{
Snejina Michailova \\ and \\ Verner Worm
}

January 2003 


\title{
PERSONAL NETWORKING IN RUSSIA AND CHINA: $B L A T$ AND GUANXI
}

\begin{abstract}
Blat and guanxi are terms describing personal networks in Russia and China respectively. They have existed and been practiced for centuries and remain highly relevant today. By employing a social network perspective, we analyze the architecture of blat and guanxi and some of the similarities between them. We also argue that personal networks in Russia and China are products of specific cultural heritages and as such have their own particular configurations and characteristics. Following a dynamic perspective, we examine how blat and guanxi have evolved over time: while they were similar in a number of dimensions during the command economy period, there are interesting signs of increasing differentiation in the post-command decade. The paper outlines important insights for Western managers and expatriates in terms of surviving in and effectively using blat and guanxi.
\end{abstract}


"Zhi ren zhong yu zhi wu" ("Who you know is more important than what you know")

- Chinese proverb

"Ruka ruku moiyet" ("One hand washes the other")

- Russian proverb

Networking is a complex phenomenon which can be approached meaningfully only in relation to a particular economic, political, social, historical, and cultural context. The actions of the members of a particular network are embedded in the wider structure of relations in which network activities are both a medium and an outcome. Due to Western (US/West European) dominance in business research, there has been less focus on personal networks than on organizational networks. Most of the work published typically relates either to firms (Alter \& Hage, 1993; Johanson \& Mattson, 1991; Granovetter, 1992; Miles \& Snow, 1986, 1992) or markets (Gerlach \& Lincoln, 1992). Personal networks, on the other hand, are predominant in most emerging markets. Although every society is built around patterned relationships among individuals, groups, and organizations, they express themselves differently in different cultural settings. We argue that personal networking in former socialist societies differs from the West in terms of how extensively it is rooted and activated in social and business life and how business success is influenced by the quality and cultivation of personal relationships. This implies that personal networks need to be managed differently in different countries in order to achieve optimal efficiency and effectiveness.

This paper focuses on personal networks in the two major formerly planned economies, Russia and China, where they are referred to as blat and guanxi respectively. In order to gain a deeper understanding of blat and guanxi, rather than merely describing the 
personal networks or examining their consequences, we need to explore what drives them and how they coevolve with their environments. What are the specific characteristics that constitute the architecture of blat and guanxi? How similar and how different are they from one another? How can Western managers not only survive but successfully work with and use blat and guanxi? These are the questions that this paper aims to answer.

There is no unified, agreed meaning of blat and the term cannot easily be translated into English. As pointed out by Joseph Berliner, one of the pioneering and most prominent researchers of the informal economy during Soviet times, the term blat is one of those many flavored words which are so intimate a part of a particular culture that they can be only awkwardly rendered in the language of another (Berliner, 1957). During socialism it was an exchange of favors of access in conditions of shortages and a state system of privileges where the favor of access was provided at public expense (Ledeneva, 1998, 1997a, 1997b). Blat served the needs of personal consumption and reorganized the official distribution of material welfare; blat exchange was often mediated and covered by the rhetoric of friendship or acquaintance: "sharing," "helping out," "friendly support," "mutual care," etc. Intertwined with other types of personal networks, blat provided access to public resources through personal channels (Ledeneva, 1997a). Restricted access was made possible through structural embeddedness: it provided information so that parties knew with whom to exchange and whom to avoid (Jones et al., 1997).

The term guanxi refers to relationships between people, but, like blat, it does not have a precise English equivalent. It implies dyadic relationships between individuals in which each can make unlimited demands on the other (Pye, 1992). Guanxi is composed of interpersonal linkages with the implication of a continued exchange of favors; it differs from friendship and simple interpersonal relationships by including reciprocal obligations to respond to requests 
for assistance (Luo, 2000). This reciprocity is socially binding and without time specification. Guanxi networks are transferable, reciprocal, intangible, and utilitarian (Park, \& Luo, 2001). Before we analyze the similarities and differences between blat and guanxi, let us outline how they differ from personal networking in the West. The key differences are listed in Table 1.

Table 1: Key Differences between Blat/Guanxi and Personal Networking in the West

\begin{tabular}{|l|l|}
\hline \multicolumn{1}{|c|}{ Blat/Guanxi } & \multicolumn{1}{|c|}{ Personal networking in the West } \\
\hline Based largely on collectivism/relationships & Based primarily on individualism \\
\hline Vitally important; often a matter of survival & Important \\
\hline Highly frequent exchanges & Exchanges are discrete in time \\
\hline Exchanges take place at the workplace & Exchanges take place outside the workplace \\
\hline Extended relationships/mediated exchanges & Dyad-based relationships/direct exchanges \\
\hline Exchanges are usually personal & Exchanges are usually nonpersonal \\
\hline
\end{tabular}

There are at least six important differences between blat/guanxi and the Western type of networking. Firstly, Confucian societies are some of the most relationship-focused societies in the world. Traditional Chinese sociologists label the USA an individualistic society and Europe a collectivist society, especially bearing in mind that most European countries have strong labor unions. Conversely, they refer to China as a relationship-based society. Guanxi has been one of the major dynamics in Chinese society throughout its history, particularly in relation to business conduct. The Chinese see business either as a war or as a relationship- 
building activity, preferably the latter. Establishing and nurturing connections, an essential component of the building of effective networks, has been pivotal to business success in all Confucian societies. In addition to being the birthplace of Confucianism, China has been ruled by a communist party for the last fifty years and has had a planned economy for most of this period. This has increased the need for personal networks. Even now when national and local state capacity in China is comparatively high, guanxi relationships with different levels of the Chinese bureaucracy are important for both Chinese and foreign business people operating in China. The emerging economic order in China has been defined as "network capitalism" (Boisot \& Child, 1999), even though China still espouses socialism as an official ideology. Secondly, in Russia and China the mediated exchange configurations are perceived as vitally important in everyday life. Thirdly, mediated exchange events take place much more frequently in these two countries compared to the Western context, i.e., Russians and Chinese encounter a far greater number of exchanges than Westerners. Fourthly, a large number of the exchanges take place at work as opposed to the Western context where, when exchanges are conducted, they are on a private basis. Fifthly, most cases in Russia and China involve persons beyond the simple dyadic relationship, while the exchange relationship in the West tends to be more dyad-based. Sixtly, since blat and guanxi are person-specific, the favors rendered are usually of a more personal nature than those performed in Western networking. Blat and guanxi rule that if there is some kind of a bond between two people, each can make a demand on the other and can expect reciprocal special consideration. For example, such favors may include taking care of the children of people who belong to the network, giving a position in a company, gaining access to a good dentist, borrowing money, etc. 


\section{Comparing blat and guanxi}

While there is a sizable body of research on guanxi, the number of studies on blat is very limited. Additionally, our search of the literature has shown that there is no published research devoted explicitly to a comparison of blat and guanxi. This understandably poses a number of challenges, particularly in terms of selecting appropriate frameworks that can allow a meaningful comparison.

The social network perspective offers a fruitful lens for exploring similarities between blat and guanxi. We have adopted the definition of social networks as collectives individuals among whom exchanges take place that are supported only by shared norms of trustworthy behavior (Liebeskind et al., 1996). The task of defining a network involves specifying the set of nodes and the relationships between them (Laumann et al., 1978). Since our interest is in what are the specific features of blat and guanxi as personal networks, how they evolve and change, we define the nodes as individuals constituting these networks and bearing the dynamics of the networks' development. At the same time, there are important differences between blat and guanxi. There is a particular way of thinking behind the two phenomena, and looking into concrete features of these ways of thinking offers a good opportunity for exploring some of these differences.

\section{Similarities between blat and guanxi from a social networks perspective}

On the basis of the literature on blat and on guanxi and detailed examination of the empirical data we have collected over the last six years (please see Appendix), we are able to identify three characteristics shared by blat and guanxi. These are: (1) social resourcing, (2) continuity of relationships, and (3) coexistence of trust and cooperation on the one hand and power and domination on the other. These three characteristics are related to either structural 
or relational embeddedness, which in turn are key notions within the social networks perspective. Structural embeddedness emphasizes social control since it provides more efficient information spread about what the members of the pair are doing, and thus a better ability to shape that behavior (Granovetter, 1992). Networks have the ability to develop and disseminate a system of shared and tacitly understood norms and rules on the one hand and a specific language on the other. This allows the network members to act appropriately, not only under well-defined conditions but also under dynamically changing contingencies. Relational embeddedness, on the other hand, is associated with the behaviors of the exchange parties, such as trust, confiding, and information sharing (Uzzi, 1997). It also refers to the degree to which exchange parties consider each other's needs and goals (Granovetter, 1992). Whereas relational embeddedness encompasses the depth and the quality of a single dyadic tie, structural embeddedness is the extent to which a dyad's mutual contacts are connected to one another, implying that a number of additional actors beyond the dyadic relationship can be in play. Below we discuss the three features of blat and guanxi in greater detail.

Social resourcing. Blat and guanxi can be viewed as a social resource because they exist in a latent form not only within one's own network but also between the blat or guanxi networks of members, the so-called set' blatnyih in Russia and guanxiwang in China. In structural embeddedness terms, blat and guanxi are not only embedded in dyadic relationships, but can be expanded to all members of the broader network. Even when blat and guanxi seem to be of a dyadic nature, exchange is often embedded in or influenced by actors outside the dyad. Thus, obligatory relations may extend to people whom one does not know directly or will never meet. One could imagine an extended network of relationships where persons A and B are involved in a dyadic relationship; B, in turn, has a dyadic relationship with $\mathrm{C}$. Thus while A 
does not know $\mathrm{C}$ directly, under set' blatnyih or guanxiwang $\mathrm{A}$ has an obligation to render a favor to $\mathrm{C}$ and vice versa.

The process of mediation of exchanges is closely related to the intensity and dynamics of social ties within the particular personal network. To use the above example $\underline{\underline{\underline{E}}}$ gine the following situation: $\mathrm{A}$, the receiver in the triad, makes a request to $\mathrm{B}$, the broker, who is unable to respond; therefore $\mathrm{B}$ passes this request to $\mathrm{C}$, the donor, who responds positively. In this case, $\mathrm{C}$ does a favor for both $\mathrm{A}$ and $\mathrm{B}$, and both $\mathrm{A}$ and $\mathrm{B}$ will feel an obligation to return the favor to $\mathrm{C}$. An additional consequence would be that after this exchange, $\mathrm{C}$ would not feel inhibited from contacting A directly if s/he needed a favor from A or her/his network. In this sense the broker plays an important role in shortening the distance between the donor and the receiver and facilitating the process of establishing trust. It is worth noting that the psychological burden for B is less than that for A since B makes a request which is not directly related to her/his own needs (Ledeneva, 1998). Several of the Russian respondents in our study wondered about outsiders' negative attitudes towards blat, since Russians used blat not to gain personally, but to help their friends or acquaintances." Blat and guanxi are hole-rich networks which can have a large number of structurally autonomous actors (Burt, 1992) and which resemble informal contracts.

Although blat and guanxi are phenomena anchored at the individual level, they become an important asset at the organizational level as personal relations are dedicated to and used by the organization. Interorganizational networks, too, are built on personal relationships, most of which persist for a long time, in many cases extending over a lifetime or beyond, i.e., passed on to successive generations. There is a widespread belief among Russians and Chinese that to succeed in business in their countries, personal networking and social connections with the appropriate authorities or individuals are often more important than the price and quality of 
the product or service or the technological expertise offered (Michailova, 2000; Tung \& Worm, 2001). The stronger the network, the more demands can be imposed. The Chinese refer to this as the "hardness" of a guanxi relationship.

Continuity of personal relationships relationships (Chamberlain, 1995; Kappel et al., 1992; Puffer \& McCarthy, 1995; Wilson \& Donaldson, 1996; Yergin \& Gustafson, 1994), and this is also true of the Chinese (Luo, 2000; Tung \& Worm, 2001; Lovett et al., 1999; Park \& Luo, 2001 Yeung, I.Y., \& Tung, R. L. 1996; Yeung \& Tung, 1996). The continuity of personal relationships is a prerequisite for the existence of blat and guanxi. These personal networks develop the ability to establish and disseminate a system of shared and tacitly understood norms and rules on the one hand and a specific language on the other, which allow the members of blat and guanxi to act appropriately not only under well-defined conditions but also under dynamically changing contingencies. The process of establishing these norms, rules, and language takes a long time, i.e., continuity of relationships is a precondition for the existence of blat and guanxi. Only through continuous interactions does it become possible to establish the conditions for developing common understandings, to define the norms of acceptable behavior, to establish trust, confide, and to share information. All these provide the foundation for social mechanisms to coordinate and adapt exchanges effectively.

Another aspect of the continuity of the relationships in blat and guanxi is associated with the fact that the person doing the favor does not expect an immediate return: reciprocation usually takes place later or much later. A Chinese respondent noted with a smile: "If I help my Danish boss I know there will be a flower outside my office next morning." The Chinese respondent would actually have preferred her boss to have waited repaying the favor 
until a time when she might really need it. This illustrates a key difference between favors in the West and in Russia and China in terms of time orientation: where Northern Europeans desire to clear such issues as soon as possible, many people in Russia and China prefer a time lag that allows them to be owed a favor for later use.

Russians and Chinese invest serious effort and considerable time into building personal relationships. These investments only pay off if the relationship can be sustained over a longer period. Several of our Russian and Chinese respondents expressed frustration at the fact that foreign expatriates come and go, often only staying in Russia or China for two years or less. This prevents them from engaging in iple and long-term projects, which would offer the opportunity of establishing good personal relationships. Using evidence from the biotechnology sector, a study concluded that relationship-specific capital, i.e., the knowledge about a particular partner and how to collaborate with that partner, becomes deeper for collaborative longer-term arrangements encompassing multiple projects than for those involving a single project (Pisano, 1989). Additionally, continuous and long-term oriented interactions allow the transfer and assimilation of tacit knowledge, which is usually impossible in short-term exchanges (Jones et al., 1997). In 1998, a questionnaire-based survey was conducted to study the problems of initiating and sustaining effective relationships with Russian business partners. The survey focused on the experiences of 14 UK organizations (e.g., commercial, academic, and governmental) across a broad range of involvement with Russia. One of the conclusions of the study was that when Russians enter into a business collaboration, they want personal relationships. This wish was ranked very highly, second after "wanting one big income." 
Coexistence of trust and cooperation and power and domination. Blat and guanxi are based to a great extent on trust. Studies of networks emphasize the notions of "trust" and “negotiation” between network members (Coulson-Thomas \& Brown, 1990; Johanson \& Mattson, 1991; Powell, 1991). Some authors suggest that interpersonal trust has fundamentally two forms - a cognitive form and an emotional form (McAllister, 1995). The cognitive form results from a reliance on a deliberate choice by the trustee regarding whom to trust, to what extent, and under what conditions. This choice is based on what we perceive as good reasons or proof of reliability. In other words, the decision to trust a person very much originates from the decision-maker's knowledge about the person s/he considers trusting. In this perspective, a person's perception of another's competence and integrity is the critical condition for trust. Emotional trust, on the other hand, is based on emotional ties between individuals, for instance friendships. Our fieldwork in Russia and China clearly demonstrates rather than cognitive trust, is more prevalent in the two countries. Many of our respondents emphasized that they value a friendship much more highly than a contract. It is usually postulated in the literature that a certain level of cognitively-based trust is a condition for the development of friendship-based trust (McAllister, 1995). This sequence seems to be reversed in the Russian and Chinese context: friendship-based trust is more likely to occur first and it may develop eventually into cognitively-based trust. This is probably the case for most collectivist societies, where some kind of friendship is a precondition for developing business relations, but it conflicts with the logic of more individualistic societies where cognitive trust is the basis for doing business. One can have a guanxi or blat without friendship, but not vice versa.

Additionally, both Russia and China have been ruled by the Communist Party for more than fifty years. During this period the Party placed itself above the law. As a result, 
rules and regulations are easily violated and this results in a propensity for people not to value contracts highly. Close personalized relationships are naturally reinforced in a context where people cannot be sure that they are protected by the law. Cooperative behavior is both necessary and strengthened for customized, complex tasks under conditions of uncertainty.

Although blat and guanxi are predominantly based on cooperation and mutual support, issues such as domination and power relations are present and should not be underestimated. They take the form of a disciplinary technology that objectifies, confirms, and reinforces the identities of selected subjects as network members. Exchanges within the network are neither random nor uniform but rather patterned, reflecting a division of labor (Jones et al., 1997). In every network there is a power structure where different actors have different powers to act and influence the action of others. This power in combination with the interest structure of the network affects its development (Hagg \& Johanson, 1988). The simultaneous existence of cooperative relationships and competitive tendencies leads to constructs such as “coopetition” (Brandenburger \& Nalebuff, 1996). Personal network relationships in Russia and China are built into hierarchical social structures. In China, they have been described as similar to the lifelong "patron-client" relationships that existed in medieval Europe (Walder, 1986), with the important difference however that subordinates have almost unlimited rights over the superior and that the balance of advantage often lies with the weaker partner in the network (Pye, 1992). Russian society views blat, influence, pulling strings, and the ability to take care of friends as important status symbols. Additionally, the more rank and power one has, the more blat one normally possesses.

The use of collective sanctions is an important feature of the structural embeddedness of blat and guanxi in the sense that network parties must know about misfeasance in order to act jointly to condemn or ostracize perpetrators (Jones et al., 1997). We do not suggest that the 
position occupied by a particular person is decisive in terms of her/his role in a particular network. Sometimes it is not the highest officials but the humblest who are in a position to do the greatest favors (Smith, 1976). Our empirical data suggest that power within blat and guanxi is perceived to be transitory, mainly due to resource asymmetries. The latter occur because of the differential flow of resources among network members, as well as their varying ability to control such flows (Gnyawali \& Madhavan, 2001). Neither blat nor guanxi are networks that tend to increase homophily, i.e., the tendency to exclude over time those players that are very different (Blau, 1977). At an individual level, heterophilous ties help determine the amount of social capital an actor can mobilize. Social capital, like human and cultural capital, facilitates an individual's success in market exchange. But whereas other forms of capital are defined as individual traits, social capital reflects a recognition of the potential advantage of being embedded in a network of ties (Coleman, 1988).

We argued earlier that blat and guanxi are hole-rich networks. A network rich in structural holes presents opportunities for control, in that the focal actor can distort information flows between disconnected actors and can leverage structural holes to control information opportunistically (Gnyawali \& Madhavan, 2001). Although the majority of our Chinese and Russian respondents perceived guanxi/blat relationships to be personal and based on trust, a number mentioned that the best kind of guanxi/blat is attained where one has some negative information about the other party. This negative information may be disclosed if the other party betrays the trust-based relationship. In this way, the other party in the relationship is held hostage to continue the linkage. This may partially explain why guanxi is sometimes viewed as a basis for illegal, corruptive business transactions. Similarly, it has been pointed out that in Russia transmitted information is often deliberately misinterpreted by both the immediate and the indirect receivers with the clear intention of harming the transmitter. Such 
misinterpretations might lead to negative consequences for the transmitter and her/his network. In this case, the receivers would be rewarded if able to "substantiate" the grounds for their intentional misinterpretation (Michailova \& Husted, 2003; Husted \& Michailova, 2002).

\section{Blat and guanxi in the command economy: similarities emphasized}

During the decades of a centrally planned economy, blat was an unavoidable necessity rather than a matter of choice. It was, to a great extent, the result of dealing with the permanent shortage of any kind of resources and consumer goods, poor quality, and intolerable delays in service, and as such it was an essential lubricant of life. Blat worked where money did not (Ledeneva, 1997a), and almost any transaction could work po blatu (through connections) or po znakomstvu (through acquaintances). Similarly, the Chinese spoke of la guanxi (using one's relationships) in such situations. The shortcomings in satisfying the vital needs of people in the socialist regime were not accidental or fugitive. Rather, they were caused by the law of "faster growth of sector I" which produced the factors of production. The imposed expansion of sector I automatically meant permanent underdevelopment and discrimination of sector II, which produced consumer goods. Furthermore, one of the leading principles of socialist planning was "more of the same," meaning that as few products as possible had to be produced in parallel by different manufacturers and consumers rather than sellers were forced to compete with one another (Kornai, 1980). In such an environment, blat became an integral part of the socialist system, a permanent feature of Soviet society. It is important to point out that coping with scarcity is not the sole source of blat-related phenomena. It resulted from the particular combination of shortages and, even if repressed, from consumerism from a paradox between an ideology of equality and the practice of differentiation through the closed distribution system (Ledeneva, 1997a). Additionally, blat 
relationships under socialism should not be confused with or equated to the exchange of goods or barter in the literal sense of the term, since they have no monetary expression: blat is associated with exchanging favors of a special kind, "the favors of access" (Ledeneva, 1997b).

Social network theorists have pointed out that organizations operate as structural constraints on personal networks, making it difficult for individuals to manipulate their own exposure to potential, new heterophilous alters, regardless of their disposition towards diversity (Popielarz, 1999). Blat under socialism was a highly efficient mechanism against the prevailing anti-individualistic attitudes and norms, and in that sense it represented an intentionally and rationally constructed phenomenon. In the socialist collectivist-autocratic system there was no place for the individual and her/his own way of thinking and behaving (Stojanov, 1992). What mattered was the class/collective interest - private interest was entirely ignored. The individual was absent in the two dogmas of communist society, dialectical materialism and historical materialism: "in $\underline{\underline{\underline{\underline{E}}}}$ ctical materialism the individual has not come into view and in rical materialism s/he is 'overcome' by the deeper notion of society" (Puchlikov, 1990). In such a context where the notion of the individual was meaningless, blat was a powerful instrument to involve a number of individuals in a complicated network based predominantly, if not solely, on personal features and the exchange of favors. It became an essential part of people's everyday lives under the motto "Tuy-mne, ya-tebe" ("You scratch my back and I'll scratch yours l'in, 2001). As China was closed to the outside world from 1960 to 1980, many important guanxi relations during that period were developed within the Chinese Communist Party based on common experiences during the war of liberation against the Japanese and later the Guomindang Party which fled to Taiwan in 1949. The strength of such guanxi relationships can be seen from the fact that Deng Xiaoping was able to rule China without any formal party, 
government, or military position from 1989 until his death in 1997 — and one could argue that he remains a central figure in Chinese politics. Hu Jintao, who took over party and state leadership in November 2002, was in reality nominated by Deng when, before he passed away, he described $\mathrm{Hu}$ as the most promising member of the fourth generation of leaders. In a more everyday context, one can take the example of a rural shop owner who denied using guanxi, as everybody paid the same price (Kipnis, 1994). However, her customers proved to be predominantly people from her own work group, and she tried to give better service to those she knew. In this way she used her guanxi to increase her turnover. In addition, her uncle, a prefect, had helped her to obtain the licence to trade, but being a member of the family she did not perceive this transaction as guanxi. The story illustrates not only the pervasiveness of guanxi in Chinese planned economy, but also that it is a blurred concept, which at least some regard as negative. Using a family member to obtain a business licence at that time was a typical application of guanxi.

Among enterprise managers guanxi and blat were to help each other fill the gaps in quotas stipulated in holes and other deficiencies in the planned economy made networking abilities a necessary competence for managers to be able to exercise basic managing functions and fulfill production targets. Promotion was also to a great extent dependent on blat and guanxi.

\section{Culturally grounded differences between blat and guanxi}

The main culturally bound differences between blat and guanxi are presented in Table 2 . 
Table 2: Culturally Bound Differences between Blat and Guanxi

\begin{tabular}{|l|l|}
\hline \multicolumn{1}{|c|}{ Guanxi } & \multicolumn{1}{c|}{ Blat } \\
\hline Neutral origin of the term & Negative origin of the term \\
\hline $\begin{array}{l}\text { Helping friends through connections is a } \\
\text { moral and social obligation }\end{array}$ & $\begin{array}{l}\text { Helping friends through connections is a } \\
\text { pleasure }\end{array}$ \\
\hline $\begin{array}{l}\text { Losing face/guanxi is perceived as having } \\
\text { drastic negative personal consequences }\end{array}$ & Losing blat is perceived as a matter of life \\
\hline Dominating holistic approach & Prevailing analytical approach \\
\hline
\end{tabular}

Origin. Guanxi is a rather neutral word in Chinese. The term originated from a rural gift economy, in particular in relation to family affairs such as marriage, funerals, etc. The concept's original connotations of family affairs have made it a positive word closely associated with Chinese family businesses, which operated in China long before 1949 (Yang, 1994; Redding, 1990). Chinese society has historically not been composed of individuals, but of families. The Chinese word jia means both "family" and "home." The family-centered society created a social fabric in China that was minimally integrated. The other main force shaping guanxi for most of China's history has been Confucianism, which emphasizes that individuals are social or relational beings. Social order would be achieved if everyone played their role properly in the hierarchical relations. According to Confucianism, an individual is basically a relational being. Confucianism ordered the relationships hierarchically among family members and modeled the state after the extended family. In Chinese society, in contrast to Russia, authority resided in state patrimonialism. Dependence was based on the fostering of personalized relationships for obtaining favors from the mandarinate (Redding, 1990). The combination of a minimally integrated society and a personalized power structure 
created the necessity for developing and maintaining guanxi, which became an increasingly sophisticated art and one of the main dynamics in Chinese society throughout its history. Guanxi is not simply a key feature of Chinese culture, but the mother of all relationships (Bian, 1997).

The word blat was originally a negative term referring to criminal activities, although it was generally used to mean less serious crimes such as minor theft. The concept was used by criminal gangs, where it forms part of their argot, and blat was mainly internalized in these circles in order to give protection against society. In the early years of the Soviet Union's existence "by blat" meant "in an illegal manner". Later on, the meaning of the term started becoming more associated with acquainting, obtaining or arranging. Although blat needs to be viewed in the context of pre-revolutionary Russian traditions of patronage and self-interested giving, it should also be distinguished from them in its extent: the types of everyday "fixing" encountered Russian society before 1917 became more widespread and systemic under the shortage economy brought into being by the Soviet state's monopoly over the official distribution of goods and services (Ledeneva et al., 2000).

Emotions versus social obligations. There is a particularistic way of thinking behind both blat and guanxi. Russia and China are positioned close to each other on the particularismuniversalism dimension: of 46 countries, Russia is third and China fifth at the particularistic end of the scale (Hampden-Turner \& Trompenaars, 2000). Particularism refers to the claim that a certain event is outside the scope of any rules and is unique $-\frac{P}{\underline{\underline{B}}}$ icularistic cultures focus on the exceptionality of present circumstances. Rules are not as important as personal relations; individuals are not managers or representatives of remote institutions, but friends, brothers, sons, or persons of unique personal importance with special claims on emotional 
involvement. Members of particularistic societies such as Russia and China have a strong tendency to divide people into two categories: those they know and can trust and those who are strangers and who could be dangerous. In-group (network) relationships are very intimate, whereas trust towards strangers is typically very low. However, if fated to work with strangers, particularists are compelled to attempt to form personalized relationships with them. Chinese and Russians feel they should help their acquaintances both from a moral and a social point of view. One loses face in China if one does not live up to one's obligations towards family, friends, and friends of friends. And one is viewed as untrustworthy in Russia if one refuses to return a favor and does not follow the reciprocity rule. However, there is an important difference: while helping friends through connections comes as a pleasure to many Russians (Wilson \& Donaldson, 1996), Chinese see helping friends as a moral and social obligation.

Chinese tend to conceal their feelings in order to fulfill their appropriate role in organizations according to societal norms, and therefore appear inscrutable (Lin, 1989). In contrast, Russians have a higher propensity to express emotions, as it is more acceptable to show personal feelings in a more individualistic society, where one is mainly responsible towards oneself. Although perceived as immoral, Russians wish to help as interpersonal trust is higher in Russia than China. The Chinese think in terms of social obligations and how they can be won or lost without destroying harmony among acquaintances or potential acquaintances. As a result of the strong collectivism among Chinese, they tend have an external locus of control, which means that harmony is particularly important for Chinese people in their relation to people they know, while it is of much less importance in relation to strangers. 
Different degree of negative consequences of losing guanxi/blat. The position of guanxi cannot be understood without recognizing that the Chinese have always been very sensitive to face and renqing (human obligations). These three concepts are intertwined: in an informal guanxi network one has to honor one's obligations to avoid losing face, which is something the Chinese are most afraid of as it means a loss of prestige for the interdependent self (Chen, 1995). In that sense guanxi and face reinforce one another. People with many personal connections have more face or prestige, which in turn makes it easier for them to establish more guanxi. The fact that there are more "face" and social obligations involved in guanxi than in blat means that breaking a guanxi bond has more radical implications for a Chinese person in terms of social and personal consequences than for a Russian who for whatever reason loses part of her/his blat connections.

Holistic versus analytical epistemology. Chinese people tend to think more holistically and synthesize, whereas Russians tend to be more analytical. The holistic approach of the Chinese means that they are highly concerned with relationships among actors and events (Nisbett et al., 2001). Instead of seeing events and actors as isolated or independent, Chinese tend to contextualize these events and actors into specific settings. In order to do that they have to know the people they are relating to comparatively well, which means that members in guanxi-wang know more about each other than Russians in set' blatnyih. The holistic approach increases the propensity to engage in broad networking, whereas a more analytical epistemology increases the propensity to build dyadic relationships. 


\section{Blat and guanxi in the market reform era: differences emphasized}

Personal networks in Russia and China could be viewed as a remnant of central planning. We argue, however, that they are more than that. Previous experiences and legacies are often regarded as barriers in the transformation process. However, they are often underestimated as relevant sources for the future. First of all, in a weak institutional system and nonexistent or poorly functioning societal frameworks and mechanisms, as in Russia and China from the beginning of the 1990s, personal networking is a highly significant resource. In a climate characterized by high uncertainty, having access to reliable information and other resources becomes vitally important. Where the political authority has been or is personal, arbitrary, unchecked, and intrusive, one can naturally find security in close personal ties. Secondly, as discussed earlier, blat and guanxi under socialism were compensatory mechanisms for the basic fundamentals of socialism — an economy of shortages and strong anti-individualism. In fact, they contributed to the development of market activities already during the socialist period and have been and continue to be an important source of entrepreneurship. If blat and guanxi were simply a legacy of central planning, one could expect that when the economy is no longer centrally planned and shortages are essentially a thing of the past, there would be no need for blat and guanxi. Although there is a generational difference in the use of the term blat, this does not mean that the phenomenon has disappeared: it is a way of investigating the resources, limitations, and consequences of the post-Soviet reformation.

Post-socialist development is marked by a high degree of uncertainty and ambiguity. The nature of blat transactions is associated precisely with reducing this degree of uncertainty: it is initiated by definite intentions and is rationally controlled. A number of authors have explored the rational design of networks and accounted for their development in terms of 
uncertainty reduction and/or environmental stabilization (Allen, 1974; Pfeffer \& Salincik, 1978; Pennings, 1981; Miles \& Snow, 1986; Hagg \& Johanson, 1988) - and the core of blat and guanxi does consists of networks. A possible explanation for the increasing importance of blat and guanxi in the post-command economy relating to performing managerial tasks and obligations is that networking increases flexibility. In an environment that continuously introduces an enormous range of contingencies, it becomes vital to be able to respond to (often suddenly and unpredictably) changing environmental and internal conditions. Networking is the most efficient way of providing the possibility to respond by gathering and disseminating information and reallocating different types of resources in a relatively fast and cheap manner.

On the more negative side, this kind of networking can create new forms of dependency and abuses of political and economic power, increasing corruption and undermining the development of an open market economy (Edwards \& Lawrence, 2000). In their questionnaire-based study from 1997 of managers in Volgograd, researchers identified an Isive network of former Communist Party functionaries who were now active in enterprise management and public administration (Edwards \& Lawrence, 2000). It was not clear whether or what links they had with the current Communist Party. However, they appeared to form a local elite encompassing the economic and political spheres.

Over the last decade both Chinese and Russian society have been commercialized and marketized. At present, every commodity, including houses, cars, and resident permits for the major metropolises, can be bought for money. Power is also something that is traded on the market, i.e., it too can be bought for money (He, 1998). Many members of the Communist Party nomenklatura or their spouses also hold positions in commercial entities. With money being the key issue to success rather than power and a market economy in development one would anticipate that blat and guanxi would be fading (Child \& Tse, 2001; Guthrie, 1998). 
However, this does not seem to be the case, at least not yet. In the case of China, this is probably partly due to the influence of Confucianism on Chinese societies, where people are socialized to think in terms of personal relations, for example information resides in networks, and partly because imperfect markets are still predominant in China. Nor has blat been abolished by the transition period in Russia. Although legal procedures have been established, informal contacts have not lost their significance: they give access to information and guarantee its reliability. Today, blat is especially necessary in relation to tax authorities, customs offices, the banking sector, and regional administration, in other words, the spheres that constitute the face of shortage at present. Gaining access to good schools and universities or to high quality medical services, for example, is a matter of activating personal networks. Blat and guanxi have become explicitly related to economic interests and the conduct of business, whereas in the socialist period it was mainly associated with political considerations and private consumption. We have observed a shift of the spheres where blat is needed and used, a shift from physical resources and assets to information flows and services.

We stated earlier that there are a number of important similarities between blat and guanxi. During the 1990s, however, with the introduction of a market-oriented economy, one can observe some important emerging differences. Whereas blat is an increasingly negative concept in Russia, especially among the well-educated young, guanxi remains a positive notion that connects people in a society based on low social trust. In China guanxi is returning to its pre-socialist content as a legitimate way of relating interpersonally in a collectivist society, where there are clear boundaries between people that are members of an in-group and others. Our Chinese respondents consistently maintained that guanxi has been increasingly exercised over the last twenty years. A similar trend can be seen among overseas whom extensive networking is a core business competence. The difference between Russia 
and China can be explained by different degrees of collectivism in the two societies, although both Russia and China are very family-oriented. China has a stronger collectivist legacy than Russia and Russia is culturally closer to European individualism.

Blat is losing its warm, human face and becoming increasingly "materialized," dominated by pragmatism and market-governed. The transformation of its nature from being based on moral and ethical considerations to having an explicit financial expression is a phenomenon in itself. Blat is becoming a negative word again with criminal undertones. China is still a pre-modern society, where nothing significant can happen without guanxi. Guanxi interaction between the government and enterprises is seen as facilitating the dynamism of market transaction in China. Characteristic of the Chinese hybrid transition system is the way in which personal connections reduce the inherent uncertainties involved in interorganizational relationships and eventually generate multiple bilateral dependence between individuals (Boisot \& Child, 1999). The distinctive character of the Chinese market system, often referred to as network capitalism, is manifested through a system of networked transactions that are based on longstanding personal connections (Boisot \& Child, 1999). Guanxi has even become more widespread after socialism, and has been further strengthen after China joined the WTO in 2001. As a respondent noted, "the WTO have created more competition between local and central government, which has made guanxi even more important for foreign business recently." It appears that competition makes access to decision-makers even more vital during the current period of China's adjustment to WTO regulations.

\section{Managerial implications}

Although knowledge of networks has expanded significantly over the last few years, the analysis of networks as a distinct empirical phenomenon remains embryonic (Koza \& 
Lewin, 1999). In this paper, we provide contributions to the understanding of personal networks in particular historical, social, cultural, and economic contexts using the examples of blat and guanxi in Russia and China. Most of the literature on networks and networking has been developed in a Western context, where the focus has been mainly on outcome and to a lesser extent on the architecture of the networks. Although there is a vast amount of literature on relationships and networks in both Western and Eastern societies, there have been few attempts to compare and contextualize networks in specific societies and thereby create a framework for making effective use of networking in different societies. Despite the currency of the slogan "think globally, act locally" over the past decade, the focus seems often to have been on the former to the exclusion of the latter.

Blat and guanxi are highly elaborated practices characterized by very complex and multifaceted dimensions. Often blat and guanxi transactions involve many steps and a number of factors. The failure to recognize that they are patterns of mentality and behavior, and as such are culturally grounded, may lead to unanticipated outcomes. There are also important lessons to be learned regarding the approach of Western owners, managers, and expatriates with assignments in Russia and China. A number face difficulties in the conduct of their dayto-day operations, in many cases due to not being able to understand and deal with the complexities and intricacies of blat and guanxi. Although Westerners tend to develop their own social networks, this is not sufficient to meet the challenges posed by the art of dealing with blat and guanxi.

- a market economy with all its market imperfections was introduced in Russia and China, networks became more affiliated to conducting business. The importance of blat and guanxi during the reform period does not seem to have waned, rather blat has become more materialized and pragmatic and less emotional and human. It has been perceived 
increasingly negatively, particularly among young people, and it has even been associated with bandit capitalism. In contrast, guanxi remains a positive notion and is even more important now than under socialism. One explanation of this difference is that Russia is a more individualistic and industrially developed country than China. It should be stated, however, that both Russia and China are currently undergoing enormous changes and it would be premature to predict what the outcome will be for the development of personalized networks. Blat and guanxi are forms of social capital that can work with or without markets.

To ensure financial success, Western business people must be familiar with and sometimes play the game of blat and guanxi. This can be done by incorporating elements of blat and guanxi in Western business strategies in Russia and China. In particular, it seems from our data that relationships with official authorities often require blat or guanxi. However, in Russia MNCs should be somewhat cautious about using blat, as it has become more materialized and can be perceived as a way of corrupting or indicating that attitudes not changed since socialism, though the concept of corruption is defined and perceived differently in different cultures. Western business people should be aware of the increasingly negative connotation of blat in particular in relation to private entrepreneurs. If they choose to engage in blat activities, it is preferable to keep these activities at a dyadic level and limit their blat connections to officials they know well. The character of criminal activities means that Western business people should in many instances avoid becoming entangled in blat activities, although blat should not be equated with bribery. In the state apparatus and certain more traditional sectors of the business community blat is still viewed differently and more human than bribery and corruption. Western business people should also be aware of the importance of blat to Russian employees and managers, and they should not try to destroy existing 
relationships as their destruction will often be counterproductive. Expatriates should not try to enter blat relations themselves, but be supportive of existing blat relations.

In China, establishing trust-based networks (guanxiwang) in the correct way will be seen as adaptation to cultural behavioral norms. It is important to be aware of the long-term orientation of guanxi as it can be regarded as a tactical misuse of knowledge of Chinese culture, which the proud and nationalistic Chinese will react strongly against. When Western companies engage in guanxi building and maintenance, it is important to be aware of the broad networking characteristics with mutual obligations and facework at stake including social pressure for harmony — there is no free lunch in China either. Legal guanxi will typically not be dyadic, but will refer to a whole set of dyadic relations or networks. The network analysis can be made at company level in order to gain an overview of the networks they are or should be involved in (Tsang, 1998). Dyadic guanxi should be reduced to a minimum among Western MNCs in China as they will often entice illegal practices. At the same time, there is an economics of guanxi meaning that there is a strong anticipation of reciprocity. Guanxi cannot be used merely to benefit Western business ventures without contributing something to the Chinese side, often in terms of personal benefits.

As guanxi connections with Chinese people and their networks, but if the Western and Chinese individuals do not know each other at all an intermediary will be preferable as it takes a great deal of time to establish trust-based relationships with strangers. Having an intermediary, preferably of Chinese origin, who assumes moral responsibility for introducing the two parties, will ensure that trust can be established relatively dy. 


\section{Appendix: Methodology}

The sample consists of 29 in-depth interviews conducted in Russia and 25 interviews conducted in China. All the interviews were conducted in manufacturing companies operating in a diverse range of industries, including chemicals, pharmaceuticals, electronics, consumer goods, energy production, textile and machine building.

The interviews in the Russian sample were conducted in the period $1996-2001$ in six companies with North European participation and in 21 purely Russian companies. The interviews in the Chinese sample took place in 40 companies with North European investments and 15 purely Chinese companies in 1997 and 2001 respectively.

Each interview took between one hour and two and a half hours depending on how much time the respondent allowed us. Although time consuming, it was considered best to elicit this information in the context of face-to-face interviews given the sensitive nature of the data being sought. The interview format allowed ample opportunity for the participants to elaborate on their response. All interviews were audio taped and transcribed verbatim.

We focused on respondents with similar background. The Western respondents were all younger, highly educated Northern European expatriates living in central metropolises in the two countries. The local Russian and Chinese respondents were living in the same cities and also well-educated but probably somewhat more international minded that the average Russian or Chinese. As our purpose in this paper is to look at the specificities of personalized networks in the business context in the two societies the data are comparable, despite the minor deviances mentioned above. 


\section{References}

Allen, N.P. 1974. The structure of interorganizational elite cooptation. American Sociological Review, 39 (3): 393-406.

Alter, C., \& Hage, J. 1993. Organizations working together. Newbury Park, Calif.: Sage Publications.

Berliner, J. S. 1957. Factory and manager in the USSR. Cambridge, MA: Harvard University Press.

Bian, Y. 1997. Bring strong ties back in: Indirect ties, network bridges and job searcher in China. American Sociological Review, June: 366-385.

Blau, P. M. 1977. Inequality and heterogeneity. New York: Free Press.

Boisot, M., \& Child, J. 1999. Organizations as adaptive systems in complex environments: The Case of China. Organization Science, 10 (3): 237- 252.

Brandenburger, A. M., \& Nalebuff, B. J. 1996. Co-opetition. New York: Doubleday.

Burt, R. S. 1992. Structural holes: The social structure of competition. Cambridge, MA: Harvard University Press.

Chamberlain, L. 1995. Volga, Volga: A voyage down the great river. London: Picador.

Chen, M. 1995. Asian Management Systems: Chinese, Japanese and Korean styles of Business. London: Routledge.

Child, J., \& Tse, D. 2001. Chinas transition and its implications for international business. Journal of International Business studies, 32 (1): 5-21.

Coleman, J. S. 1988. Social capital in the creation of human capital. American Journal of Sociology, 94 (Supplement): 95-S120.

Coulson-Thomas, C., \& Brown, R. 1990. Beyond quality: Managing the relationship with the customer. Corby: British Institute of Management.

Edwards, V., \& Lawrence, P. 2000. Management in Eastern Europe. NY: Palgrave.

Gerlach, M., \& Lincoln, J. 1992. The organization of business networks in the U.S. and Japan. In R. Eccles (Ed.), Networks and Organization, Cambridge MA: Harvard University Press.

Gnyawali, D. R., \& Madhavan, R. 2001. Cooperative networks and competitive dynamics: A structural embeddedness perspective. Academy of Management Review, 26 (3): 431-445. 
Granovetter, M. 1992. Problems of explanation in economic sociology. In N. Nohria, \& R.G. Eccles (Eds.), Networks and organizations: Structure, form, and action: 25-56, Harvard Business School Press.

Guthrie, D. 1998. The Declining Significance of Guanxi in China's Economic Transition. China Quarterly, 154: 254-282.

Hagg, I., \& Johanson, J. 1988. Firms in networks: New perspective on competitive power. Mimeo, Center for Business and Policy Studies, University of Uppsala.

Hampden-Turner, C. \& Trompenaars, F. 2000. Building cross-cultural competence. Chichester: John Wiley \& Sons, LTD.

He, Q. L. 1998. Xiandaihua de Xianjing (The fall of Modernisation). Beijing: China Today Publishing.

Husted, K. \& Michailova, S. 2002. Knowledge sharing in Russian companies with Western participation. International Management, 6 (2): 17-28.

Il'in, V. 2001. Podarok kak social'nuy phenomen. Tezisyi lekcii. Moskva: Centr sociologicheskogo obrazovanija pri institute sociologii RAN. (The present a social phenomenon. Theses of a lecture. Moscow: Center of Sociological Education at the Institute of Sociology at the Russian Academy of Sciences) Published on www.socnet.ru

Johanson, J., \& Mattson, L.G. 1991. Interorganizational relations in industrial systems: A network approach compared with the transaction-cost approach. In G. Thompson, K. Frances, R. Levacic, \& J. Mitchell (Eds.), Markets, hierarchies and networks: The coordination of social life, London: Sage.

Jones, C., Hesterly, W., \& Borgatti, S. P. 1997. A general theory of network governance: Exchange conditions and social mechanisms. Academy of Management Review, 22 (4): 911945.

Kappel, G., Rathmayr, R., \& Diejhl-Zelonkina, N. 1992. Verhandeln mit Russen: Gesprächsund Verhaltensstrategien für die interkulturelle Geschäftspraxis. Vienna: Service Verlag.

Kipnis, A. 1994. What is a Guanxi. Paper presented at the Association of Asian Studies' annual conference, Boston.

Kornai, J. 1980. Economics of shortage. Amsterdam: North-Holland.

Koza, M. P., \& Lewin, A. Y. 1999. The coevolution of network alliances: A longitudinal analysis of an international professional service network. Organization Science, 10 (5): 638653.

Laumann, E. O., Galaskiewicz, J., \& Marsden, P. V. 1978. Community structure as interorganizational linkages. Annual Review of Sociology, 4: 455-484. 
Ledeneva, A. V. 1997a. Practices of exchange and networking in Russia. Soziale Welt, 48: 151-170.

Ledeneva, A. V. 1997b. Neformal'naya sphera i blat: grazhdanskoe obshestvo ili (post)sovetskaya korporativnost' (The informal sphere and blat: civil society or (post)Soviet corporativeness). Pro et contra, 2 (4): 113-124.

Ledeneva, A. V. 1998. Russia's economy of favors: Blat, networking and informal exchange. Cambridge: Cambridge University Press.

Ledeneva, A.; Lovell, S \& Rogachevski, A. 2000. Introduction. In S. Lovell, A. Ledeneva \& A. Rogachevski (Eds.), Bribery and Blat in Russia: Negotiating reciprocity from the middle ages to the 1990s: 1-19. Macmillan Press and St.Martin's Press.

Liebeskind, J. P., Oliver, A. L., Zucker, L., \& Brewer, M. 1996. Social networks, learning, and flexibility: Sourcing scientific knowledge in new biotechnology firms. Organization Science, 7: 428-443.

Lin, Y. 1989. My Country and my People. Singapore: Heinemann Asia. First published in 1936.

Lovett, S., Simmons, L. \& Kali, R. 1999. Guanxi versus the market: Ethics and efficiency. Journal of International Business Studies, 30 (2): 231-247.

Luo, Y. 2000. Guanxi and business. Singapore: World Scientific.

McAllister, D. J. 1995. Affect-and cognition-based trust as foundations for interpersonal cooperation in organizations. Academy of Management Journal, 38 (1): 24-59.

Michailova, S. 2000. Contrasts in culture: Russian and western perspectives on organizational change. The Academy of Management Executive, 14 (4): 99-112.

Michailova, S. \& Husted, K. 2003. Knowledge sharing hostility in Russian firms. California Management Review, forthcoming in Winter.

Miles, R. E, \& Snow, C. C. 1992. Causes of failures in network organizations. California Management Review, 34 (4): 53-72.

Miles, R. E., \& Snow, C. C. 1986. Organizations: New concepts for new forms. California Management Review, 28 (3): 62-73.

Nisbett, R.E., Peng, K., Choi, I., \& Norenzayan, A. 2001. Culture and systems of thought: Holistic vs Analytic cognition. Psychological Review, 109: 291-310.

Park, S. H., \& Luo, Y. 2001. Guanxi and organizational Dynamics: Organizational network in Chinese Firms. Strategic Management Journal, 22: 455-477. 
Pennings, J. 1981. Strategically interdependent organizations. In P. Nystrom, \& W. Starbuck (Eds.), Handbook of organizational design, Oxford: Oxford University Press.

Pfeffer, J., \& Salincik, G. 1978. The external control of organizations. New York: Harper \& Row.

Pisano, G. P. 1989. Using equity participation to support exchange: Evidence from the biotechnology industry. Journal of Law, Economics, and Organization, 51: 109-126.

Popielarz, P. A. 1999. Organizational constraints on personal network formation. Research in the Sociology of Organizations, JAI Press, 16: 263-281.

Powell, W.W. 1991. Neither market nor hierarchy: Network forms of organization. In G. Thompson, K. Frances, R. Levacic, \& J. Mitchell (Eds.), Markets, hierarchies and networks: The coordination of social life, London: Sage.

Puchlikov, V. 1990. Tschelovek i obstestvo. K probleme gumanizacii socialno-philosophskogo mishlenija. Moskwa: Nauka (Man and Society. Toward the Problem of Humanization of Social-Philosophical Thought, Moscow, Science).

Puffer, S., \& McCarthy, D. 1995. Finding the common ground in Russian and American business ethics. California Management Review, 37 (2): 29-46.

Pye, L. 1992 Chinese commercial negotiatiing Style. Cambridge, MA: Oelgeschlager, Gunn \& Hain.

Redding, G. 1990. The Spirit of Chinese Capitalism. Berlin: Walter de Gruyter.

Smith, H. 1976. The Russians. New York: Times Books.

Stojanov, Ch. 1992. The post-socialist transformation: a unique (re)-moderinization? Research In Social Movements, Conflicts and Change, 14: 211-235.

Tsang, E. 1998. Can guanxi be a source of sustained competitive advantage for doing business in China. Academy of Management Executives, 12 (2): 64-73.

Tung, R., \& Worm, V. 2001. Network Capitalism: The role of Human Resources in penetrating the China Market. International Journal of Human Resource Management, 12 (4): 517- 534.

Uzzi, B. 1997. Social structure and competition in interfirm networks: The paradox of embeddedness. Administrative Science Quarterly, 42: 35-67.

Walder, A. 1986. Communist and Neo-traditionalism: Work and Authority in China. Berkeley, Ca.: University of California Press. 
Wilson, D., \& Donaldson, L. 1996. Russian etiquette \& ethics in business. Chicago, Illinois: NTC Business Books.

Yang, M. M. 1994. Gifts, favors and banquets: The art of social relationships in China. Ithaca-London: Cornell University Press.

Yergin, D., \& Gustafson, T. 1994. Russia 2010 and What It Means for the World. New York: Vintage.

Yeung, I.Y., \& Tung, R. L. 1996. Achieving business success in Confucian societies: The importance of guanxi (connections). Organizational Dynamics, 25 (2): 54-65. 